\title{
GRUPOS DE APRENDIZAGEM NAS AULAS DE FÍSICA: AS INTERAÇÕES ENTRE PROFESSOR E ALUNOS
}

\author{
Learning groups in Physics classroom: \\ the interactions between teacher and students
}

\author{
Glauco dos Santos Ferreira da Silva ${ }^{1}$ \\ Alberto Villani ${ }^{2}$
}

\begin{abstract}
Resumo: Em nosso trabalho buscamos entender a dinâmica que se estabelece na sala de aula quando são introduzidas atividades de grupos, analisando o processo grupal e sua relação com o ensino-aprendizagem da Física. Por isso, optamos por um estudo das relações estabelecidas no grupo entre os seus membros (alunos e professor) e das estratégias criadas em conjunto para a resolução da atividade. Como referencial teórico, utilizamos as concepções de grupo operativo de Pichon-Rivière, que focaliza a tarefa do grupo e o vínculo entre os membros como elementos essenciais do desenvolvimento grupal. O nosso trabalho consistiu em uma análise diacrônica e sincrônica das interações dos alunos de um dos grupos que compunha a classe em duas aulas diferentes: a primeira antes de uma intervenção institucional do professor, que atribuiu funções para cada um dos membros do grupo; e a segunda depois desta intervenção.
\end{abstract}

Palavras-chave: Ensino de Física. Grupo operativo. Interação professor-aluno.

\begin{abstract}
This work aims to understand the dynamics that is established in the classroom when group activities are introduced. Our main focus is in understanding of group processes and their relation to the Physics teaching and learning. We studied the relations established in the group between their members and the strategies used during the activity in a Physics classroom in High School. For this work we used the conceptions of "operative groups" as described by Pichon-Rivière, who focuses on the task of the group and on the bonds between its members as essential elements in the group's development. Our work consists of an analysis of the interactions at two different moments for the group: the first one before a teacher's initial intervention that gave specific functions to each member of the group, and the second one after this intervention.
\end{abstract}

Key words: Physics teaching. Operative group. Interaction teacher-pupil.

${ }^{1}$ Doutorando em Ensino de Ciências (Modalidade Física), Universidade de São Paulo (USP). Docente, Curso de Licenciatura em Física, Instituto Federal de Educação, Ciência e Tecnologia de São Paulo (IFSP), São Paulo, SP.glaucosfs@gmail.com

${ }^{2}$ Livre docente em Ensino de Física. Professor Associado do Instituto de Física da Universidade de São Paulo (USP).avillani@usp.br

${ }^{1}$ Rua Pedro Vicente, 625

Canindé - São Paulo, SP, Brasil

01.109-010

21

Ciência :̊ Educação, v. 15, n. 1, p. 21-46, 2009 
Silva, G. S. F.; Villani, A.

\section{Introdução}

É muito difundida a opinião de que organizar a sala de aula em pequenos grupos constitui uma opção didática bastante favorável à aprendizagem dos alunos. Para vários autores (COLL, 2000; HELLER et al., 1999; HAKE, 1998; KIRSCHNER, 1992) e para os próprios Parâmetros Curriculares Nacionais - PCN (BRASIL, 2002), o trabalho com grupos permite que os estudantes sejam protagonistas do próprio aprendizado, pois nessa situação é possível:

- Promover a cooperação e o debate de idéias entre os estudantes, fazendo com que estes aprendam a ouvir e se fazerem ouvir;

- Permitir aos estudantes elaborarem suas próprias argumentações, promovendo, entre eles, o uso da linguagem científica.

- Promover habilidades que ajudem os estudantes a resolverem exercícios quando estiverem sozinhos.

Acreditamos que a compreensão do processo grupal nos ambientes de ensino-aprendizagem de Ciências (sala de aula, laboratórios, etc.) seja importante no que diz respeito à ação do professor nesses ambientes. Em nossa opinião, isso permitiria que o professor favorecesse tanto a aprendizagem dos conteúdos específicos, quanto o desenvolvimento de habilidades de comunicação e de atuação dos atores envolvidos. Em particular, explorando os pequenos grupos seria possível introduzir na sala de aula situações peculiares de interação e de ensinoaprendizagem pouco contempladas nesses ambientes onde, em geral, os alunos interagem somente com o professor ouvindo-o ou respondendo às suas perguntas.

Encontramos o trabalho de Hake (1998) que nos pareceu interessante no tocante aos seus resultados. Ele fez uma ampla investigação envolvendo mais de seis mil alunos em turmas de Física, tanto do Ensino Superior quanto do Ensino Médio. Ele aplicou pré e pós-testes para alunos que utilizavam atividades em grupos (engajamento interativo) e para outros cujas aulas eram caracterizadas pelo aspecto tradicional, com exposição de conteúdo pelo professor. Os resultados obtidos por intermédio do ganho normalizado ${ }^{3}$, calculado com base nas médias dos pré e pós-testes, foram superiores para os alunos do engajamento interativo em relação aos que tinham aulas tradicionais.

Outro trabalho interessante diz respeito a uma organização de pequenos grupos para a resolução de problemas em Física. Trata-se da proposta de Heller et al. (1999), que estimulou os alunos com as atividades em grupo ao tentar modificar um contexto usual na sala de aula onde estudantes se encontravam pouco interessados na aprendizagem da disciplina. Para a sua realização, foram introduzidas algumas funções que deveriam ser rotativas a cada aula e a cada atividade, de maneira que todos os estudantes participassem de forma ativa e variada na realização da mesma.

${ }^{3}$ O ganho "normalizado" é calculado pela razão entre a diferença das médias de pós e pré-testes e a diferença de 100 e a média do pré-teste (ou seja, a razão entre o ganho obtido no pós-teste e o ganho possível). 
A idéia principal dessas funções era tentar facilitar a comunicação entre os alunos e entre estes e o professor, evitando que surgissem estereotipias dentro do grupo, tais como: sempre o mesmo aluno fala, sempre o mesmo faz tudo sozinho, ou, ainda, sempre o mesmo não faz nada. As funções introduzidas foram: Líder, responsável pela execução da tarefa; Anotador, quem deveria registrar cada etapa das discussões do grupo; Questionador, responsável por questionar os resultados que o grupo encontrasse na resolução da tarefa ${ }^{4}$.

Também os resultados da pesquisa de Barros et al. (2004) nos pareceram animadores. Em uma disciplina de Física I (Mecânica Newtoniana), ministrada para cursos de graduação da área das Ciências Exatas, foram organizados pequenos grupos e estruturados mediante a rotação das funções de Líder, Anotador e Questionador. Os autores se apropriaram do modelo de Heller et al. (1999) e da expressão matemática do ganho normalizado de Hake (1998). Nesse contexto, pré e pós-testes foram aplicados: os valores dos ganhos normalizados foram significativamente maiores para as turmas com atividades de grupo.

Diante dos resultados dessas pesquisas, nos perguntamos: como ocorrem as interações em um grupo de ensino-aprendizagem de Física? Quais as dificuldades que o grupo enfrenta para alcançar os resultados? Como se estabelecem as intervenções do professor no grupo? Geralmente, esse tipo de intervenção (inserção das funções) é suficiente para ajudar o grupo a alcançar os resultados desejados?

Refletir sobre esse tipo de questão torna-se necessário uma vez que a dinâmica da sala de aula passa por mudanças estruturais quando os grupos são inseridos como atividade principal durante as aulas. Nesse sentido, Anzieu e Martin (1971) afirmam que "as ações de um grupo se distinguem das ações individuais, porque se trata de uma pluralidade" (p. 22, tradução nossa). Outra percepção é que as relações entre professor, alunos e tarefa são transformadas na medida em que os estudantes saem de uma postura "passiva", apenas respondendo quando solicitados, para uma em que se exige sua participação mais efetiva. Afirmamos com isso que, dentro desse contexto de ensino-aprendizagem, as relações aluno-professor-aluno adquirem novo formato.

Em nosso trabalho buscamos entender a dinâmica que se estabelece na sala de aula quando tal mudança aí ocorre, em virtude das atividades de grupos. O nosso foco principal está na compreensão do processo grupal e sua relação com o ensino-aprendizagem da Física. Por isso, optamos por um estudo das relações estabelecidas no grupo entre os seus membros (alunos e professor) e das estratégias criadas em conjunto para a resolução da atividade.

Apresentamos, neste artigo, o caso de um grupo de estudantes da primeira série do Ensino Médio que se reuniram em duas aulas distintas para a resolução de exercícios de Física, propostos pelo professor. A nossa análise foi conduzida pelo referencial teórico de grupo

\footnotetext{
${ }^{4}$ As funções que os alunos assumiam haviam sido outorgadas pelo professor da disciplina, mas eram os alunos quem decidiam qual função cada um deveria exercer. A única regra era que fosse de forma rotativa, isto é, quem tivesse assumido a função de Líder numa aula deveria assumir outra, assim por diante.
} 
Silva, G. S. F.; Villani, A.

operativo (PICHON-RIVIÈRE, 2005). Usamos os seus conceitos de tarefa e vínculo para identificar as fases do processo grupal, os quais serão explicados na terceira parte do presente texto. Focalizaremos as configurações da comunicação (convergente, divergente, difusa) entre os membros do grupo e as intervenções do professor (presencial e institucional) (SILVA, 2008) para caracterizar a relação entre a rede de comunicação do grupo e as ações do professor. Como resultado, concluímos que esse grupo experimentou uma mudança no conjunto de sua comunicação, favorecendo uma participação mais efetiva dos alunos em seu processo de ensino-aprendizagem.

\section{Procedimentos metodológicos da pesquisa}

Utilizamos a pesquisa qualitativa tendo como base a observação participante, ou seja, o pesquisador imerso no campo. É comum atribuir a esse tipo de pesquisa o título de interpretativa, visto que, segundo Moreira (1990, p. 32), o interesse central da investigação está "na questão dos significados que as pessoas atribuem a eventos e objetos, em suas ações e interações dentro de um contexto social, e na elucidação e exposição desses significados pelo pesquisador".

As idéias de Lüdke e André (1986) sintetizam a pesquisa qualitativa: (i) o ambiente natural torna-se fonte direta dos dados e o pesquisador o instrumento principal; (ii) os dados têm uma característica descritiva; (iii) preocupa-se mais com o processo do que com o produto; (iv) a interpretação do pesquisador dos significados que as pessoas dão às coisas e a sua vida; (v) a análise tem uma tendência a seguir um processo indutivo. Contudo, recentemente, há vários outros caminhos que vêm sendo tentados com a finalidade de se aprimorarem a qualidade e relevância dos resultados (BAROLLI, VALADARES, VILLANI, 2007). Em uma publicação importante de Santos e Greca (2006), encontramos um compêndio de algumas metodologias utilizadas para a pesquisa em Ensino de Ciências: subsídios para a pesquisa entre educação científica e cultura; aprimoramento de captação e armazenamento digitais, sofisticação em entrevistas e análise de discurso.

Nessa perspectiva, acrescenta-se aos nossos procedimentos metodológicos o fato de este trabalho estar vinculado a um grupo de pesquisadores que pretende explorar as contribuições da Psicanálise para a pesquisa em Ensino de Física. Buscamos, assim, situações que podem ser interpretadas de maneira satisfatória pelo referencial da psicanálise individual ou grupal, focalizando "as diferentes relações que os sujeitos adotam ante o conhecimento e os condicionantes subjetivos que fazem com tais relações se estabeleçam daquela forma" (VILLANI et al., 2006, p. 325).

A diferença, então, consiste no fato de que o referencial teórico permite deslocar os tipos de problemas que são atacados tradicionalmente, pois

o centro das atenções deixou de ser a dificuldade do aprendiz em entender os vários conceitos científicos [...] e passou para a tentativa de compreender sua resistência em iniciar uma busca do conhecimento e sua fragilidade em sustentar o esforço necessário numa procura ou, ao contrário, seu investimento na aprendizagem. (VILLANI et al., 2006, p. 326) 
Grupos de aprendizagem nas aulas de Física: ...

Acreditamos ser promissor optar por essa forma de conduzir as pesquisas e a análise dos dados, já que podemos incluir elementos da subjetividade, tanto dos sujeitos da pesquisa (professor e alunos, em nosso caso) quanto do pesquisador.

Por fim, fazemos uma recuperação a posteriori dos dados, por meio do questionamento dos pares ao pesquisador, construindo uma história marcada por fases que são determinadas por momentos de dificuldades, de impasses ou de sucessos que os sujeitos da pesquisa - professor e alunos - experimentam: "a função é permitir que elementos de natureza inconsciente, ou ao menos não explicitamente conscientes, [do pesquisador] na ocasião dos eventos, possam ser recuperados" (BAROLLI, VALADARES, VILLANI, 2007, p. 255). Logo, a análise é conduzida de forma que o grupo de pesquisadores esteja numa posição de "atenção flutuante", para que, no processo de "livre associação", permita-se a emergência de novos elementos da pesquisa relatada (BAROLLI, VALADARES, VILLANI, 2007). Em nosso trabalho, a interpretação final referente à mudança do grupo foi elaborada com base nas sugestões dos pares, até se encontrar uma hipótese satisfatória.

O nosso ambiente de pesquisa foi uma sala de aula em uma escola particular, numa cidade do Estado de São Paulo, na qual estudavam 12 alunos formando três grupos (houve uma pequena flutuação do número de estudantes ao longo do ano letivo, mas não no número de grupos). A escola era de médio porte e considerada tradicional por seus diretores. A opção por trabalhos em grupo durante as aulas foi iniciativa do professor, influenciado por seu trabalho de mestrado (FERNANDES, 2007) e por pertencer ao nosso grupo de pesquisadores.

O registro das aulas foi feito por meio de notas de campo e mediante recurso de audiovisual; a filmadora era colocada na sala de aula posicionada sempre perto de um dos grupos, a fim de que se registrassem as falas e os gestos dos alunos, bem como as intervenções do professor no grupo. No final da experiência foram feitas entrevistas com os alunos e o professor.

\section{Referencial teórico: grupos operativos}

Para conduzir nossa análise utilizamos as concepções de Enrique Pichon-Rivière referentes à sua teoria de grupo operativo (PICHON-RIVIÈRE, 2005). As suas idéias centrais giram em torno da tarefa e do vínculo, que vão se constituindo a partir da comunicação entre os membros do grupo. Assim, um grupo operativo pode ser definido como um conjunto de pessoas que tenham um objetivo em comum e que buscam abordá-lo em equipe enquanto operam (BLEGER, 2001).

O fator principal de se considerar que há um objetivo comum é perceber que os membros do grupo devem realizar um trabalho comum ou uma tarefa comum para alcançarem estes objetivos. Essa idéia é importante, pois "a tarefa é um organizador dos processos de pensamento, de comunicação e de ação que ocorrem na situação de grupo" (FERNANDES et al., 2003, p. 197). A tarefa, para Pichon-Rivière (2005) possui duas dimensões: uma explícita e outra implícita. A primeira diz respeito ao objetivo direto do grupo, ou seja, o trabalho a ser produzido que, no caso da aprendizagem de Física, pode ser um exercício (vide análise) ou a realização de uma experiência de laboratório ou oficina de Física (ROCHA, 2005). Já a tarefa implícita se caracteriza pela manutenção da coesão do grupo e a superação dos montantes de 
Silva, G. S. F.; Villani, A.

ansiedades que são despertadas durante a realização da tarefa explícita. Portanto, o grupo deve superar os obstáculos surgidos, como, por exemplo, a formação de subgrupos dispersivos, e manter a esperança de que a meta poderá ser atingida.

O processo grupal é marcado pelas relações entre sujeitos, e admitimos que há dois níveis que operam no grupo: o da intencionalidade consciente e o da interferência dos fatores inconscientes. O referencial de grupos operativos dá conta, em certa medida, de nos informar sobre o segundo, pois ele focaliza os elementos que mobilizam as estruturas internas dos sujeitos, fazendo com que eles superem suas dificuldades de aprendizagem e comunicação. Isso implica dizer que, ao operar em grupo, o sujeito revela aquilo que está implícito por meio de comportamentos repetitivos que interpretamos como "sintomas" de algo que não está caminhando bem (PICHON-RIVIÈRE, 2005).

Esses sintomas, que podem representar dificuldades para o sujeito em ação, surgem pelo fato de que há um mundo interno do sujeito que é construído por um processo progressivo de internalização de objetos e relações. Dentro dele tenta-se reconstruir a realidade exterior, mas, na passagem do "fora" para o "dentro", este cenário exterior sofre algumas modificações. O que se observa no processo é um aspecto dinâmico de intersubjetividades dos mundos interno e externo. Pichon-Rivière (2005) usa essa noção para a sua definição de vínculo, o qual é definido "como uma estrutura complexa que inclui um sujeito, um objeto e sua mútua inter-relação com processos de comunicação e aprendizagem" (PICHON-RIVIĖRE, 2005, p. 5).

A dinâmica grupal é marcada pela assunção e adjudicação de papéis. Segundo PichonRivière (2005), são quatro os principais: porta-voz, líder, bode expiatório e sabotador. O porta-voz que surge diante de uma necessidade de anunciar ou denunciar um acontecer grupal, que está relacionado com uma situação latente no âmbito do grupo (muitas vezes, um dilema no fazer da tarefa). Então, se abrem duas possibilidades: ou os demais membros encaram as dificuldades e passam a resolvê-las, ou o grupo entende que esta dificuldade é somente daquele sujeito. No primeiro caso, o porta-voz vai se tornar o líder da tarefa, e o grupo inicia um momento de cooperatividade. No entanto, se o porta-voz não é ouvido, ele passa a ser o bode expiatório do grupo e os outros passam a hostilizá-lo de modo sutil, pois não reconhecem sua mensagem. Há ainda, dentro desse processo, o papel do sabotador, que surge quando o nível de ansiedade é tal que fugir da tarefa lhe parece mais agradável do que ter de realizá-la. Ele cria outras necessidades como sendo mais importantes e tenta levar o grupo a seguir seus passos.

No caso do líder, ele pode ser classificado em quatro tipos diferentes: democrático, autocrático, demagógico ou laissez-faire. O líder democrático vai ajudar o grupo a sair de uma situação dilemática. Enquanto o autocrático é o tipo 'tirano', que dá as ordens. O demagógico vai atuar mantendo uma aparência democrática. Enquanto o último, laissez-faire, é aquele que não assume nenhum compromisso diante do grupo.

Com base na observação de determinados comportamentos grupais, Pichon-Rivière propôs uma escala de avaliação da dinâmica relacional. O primeiro grau de identificação com a tarefa e com o grupo é a afiliação, quando o integrante se aproxima, mas ainda com um distanciamento. No momento seguinte, há um maior grau de identificação e integração grupal, permitindo a elaboração da tarefa - atingiu-se a pertença. Em seguida há uma contribuição, ainda que silenciosa, à tarefa grupal: a cooperação. O grupo, então, coloca-se direcionalmente sobre a tarefa, atingindo a pertinência. A comunicação é fundamental nesse processo de 
Grupos de aprendizagem nas aulas de Física: ...

interação grupal, podendo ser verbal, pré-verbal ou gestual. Depois acontece a aprendizagem, caracterizada por uma mudança qualitativa do grupo, implicando em criatividade, resolução das ansiedades e uma adaptação ativa à realidade. Tem-se ainda a telê, que é o clima em que se desenvolve o grupo, resultado de uma transferência positiva ou negativa para trabalhar a tarefa grupal.

O grupo, enquanto opera, passa por três fases que estão relacionadas com o grau de envolvimento na resolução da tarefa, a saber: pré-tarefa, tarefa e projeto. Na pré-tarefa encontramos um amplo uso de técnicas defensivas dos membros do grupo a fim de evitar a realização da atividade. Essa fase é marcada por momentos de dispersão dos alunos e de uma estereotipia dos papéis. Já na tarefa, o sujeito modifica sua atitude em relação às mudanças propostas, saindo de uma posição defensiva; também ocorre uma quebra de estereótipos e o objeto de conhecimento se torna penetrável. Há um movimento que direciona o grupo desde o implícito para o explicito. Finalmente, no projeto, o grupo pode propor objetivos para além do "aqui e agora" e planejar o futuro; cada componente do grupo vai assumindo sua "nova" identidade, melhor adaptado à realidade com a qual ele interage, passando a funcionar de maneira original e como um grupo operativo. É nessa fase que acontece um interjogo dos papéis com maior intensidade.

\section{Comunicação, processo grupal e aprendizagem}

Tendo em vista o referencial de grupos operativos, buscamos os elementos constituintes de seu corpo teórico e imaginamos um sistema de representação para o processo grupal de aprendizagem, que identifica algumas configurações inerentes ao processo (SILVA, 2008). Essas configurações surgem devidas à comunicação e a geração de vínculos entre os membros do grupo, e são caracterizadas pelas relações intersubjetivas que vão se estabelecendo entre eles, o que caracteriza, de certo modo, a aprendizagem do grupo.

Os sistemas de comunicação estão representados por figuras que mostram os alunos e como se encontra a rede de comunicação entre eles. Para tanto, utilizamos flechas que indicam a direção da fala deles. Parece que fica mais claro se usarmos a analogia de linhas de telefone: as setas entre os membros do grupo indicam a origem e o destino dos canais de comunicação. No caso de setas duplas, a iniciativa de comunicação provém de ambos os lados.

\section{Modelos de comunicação do processo grupal}

Uma primeira configuração que o grupo pode experimentar é o sistema de comunicação convergente, que é assim marcado porque a comunicação converge para um dos membros do grupo. No exemplo mostrado na figura 1, os alunos 2, 3 e 4 abrem um canal de comunicação com o aluno 1, podendo estabelecer com ele um vínculo positivo (reconhecendo sua liderança naquele momento) ou negativo (colocando-o como bode expiatório).

Encontramos um sistema de comunicação divergente, representado na figura 2, na qual é evidenciado que a comunicação parte de um e é dirigida para todos. Nesse caso identificamos duas possibilidades: assunção do papel de porta-voz ou do líder. No primeiro caso alguém denuncia um acontecer grupal, ou seja, em um dado momento, um membro vai 
Silva, G. S. F.; Villani, A.

se colocar em destaque no grupo para comunicar algo importante e que está latente. No segundo, o destaque entre os membros do grupo pode ser assumido por um líder do tipo autocrático de quem sai uma voz de comando para os alunos (veremos uma situação desta na análise dos dados).

Há um sistema intermediário entre a convergência e a divergência no exemplo da figura 3, na qual as setas duplas indicam uma diferença das duas situações anteriores. $\mathrm{O}$ aluno 1 dialoga efetivamente com os alunos 2, 3 e 4; entretanto não há comunicação entre estes últimos.
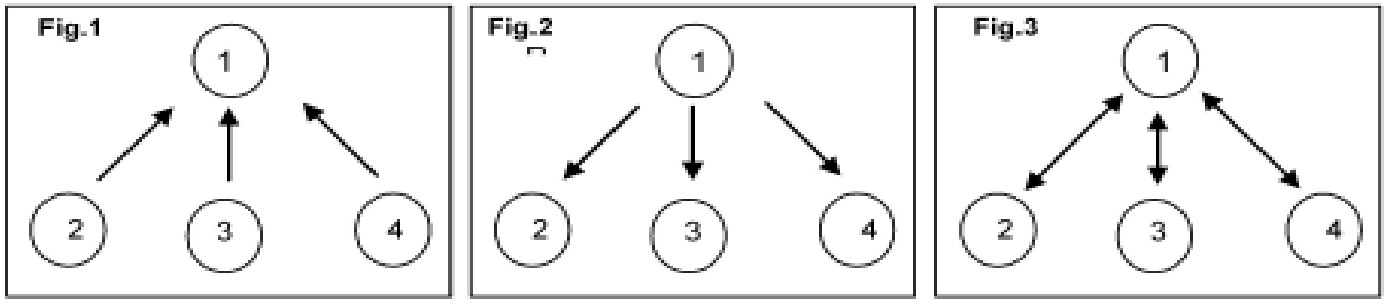

Fig. 1. Sistema de comunicação convergente (indicando o papel de líder ou de bode expiatório);

Fig. 2. Sistema de comunicação divergente (a mensagem parte de 1 para o demais membros do grupo);

Fig. 3. Canais de comunicação duplos (somente entre os subgrupos indicados).

Pichon-Rivière (2005) afirma que a aprendizagem só se dá à medida que a rede de comunicação do grupo seja constantemente reajustada. Se as configurações anteriores predominam por muito tempo no grupo, é gerada então uma estereotipia e torna-se necessário que o próprio grupo trabalhe a fim de superá-las, pois isto constitui parte da tarefa implícita. Caso isso não aconteça, é necessária a intervenção do professor para "perturbar" a rede de comunicação a fim de favorecer uma nova situação, em que os papéis comecem a circular.

Quando o professor chega ao grupo, ele deve abrir canais de comunicação com todos os estudantes e, além disto, perceber os pedidos de abertura que vêm deles e quais são as mensagens que estão lhe enviando. A presença do professor no grupo pode ser representada nas figuras $4 \mathrm{a}$ e 4b, que indicam novas configurações. Na medida em que o professor interage com o grupo, aquela situação convergente ou divergente tende a se desfazer porque os alunos começam a interagir de maneira a quebrar a estereotipia. Na figura $4 \mathrm{~b}$ indicamos a "perturbação" mediante as setas que ligam os alunos: trata-se de uma situação de transição, na qual é evidenciado o efeito causado pelo docente, mesmo que nem todos os alunos estejam se comunicando entre si.

Após a saída do professor, uma nova situação pode ser gerada se a sua intervenção favoreceu a quebra da estereotipia. A comunicação do grupo se estabelece de forma a gerar um sistema de comunicação difusa (figura 5), em que há uma interação entre todos os membros do grupo e uma circulação dos papéis, não havendo um canal de comunicação privilegiado. 
Grupos de aprendizagem nas aulas de Física: ...
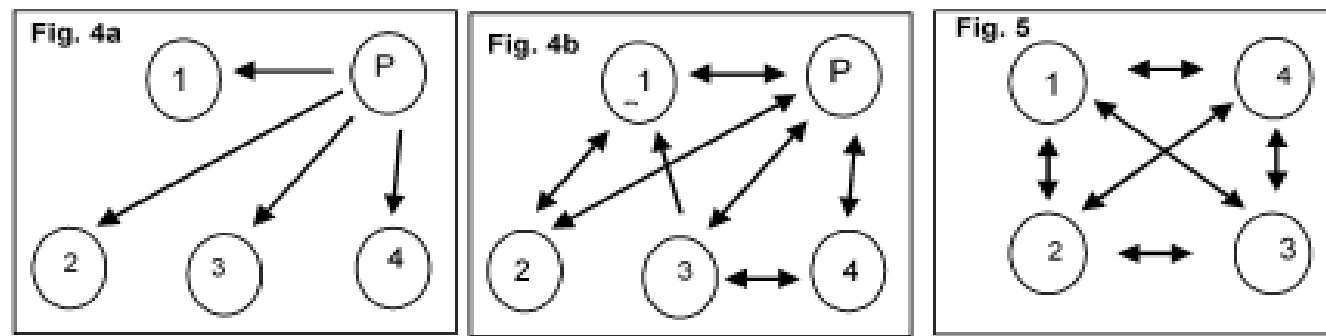

Fig. 4a. O professor faz uma intervenção no grupo abrindo canais de comunicação com os alunos;

Fig. 4b. durante a presença do professor no grupo, os alunos vão interagindo aos poucos;

Fig. 5. A comunicação nesta configuração entre os alunos é difusa.

\section{Aprendizagem no processo grupal}

Todo aquele processo é dinâmico e à medida que o grupo aprende a lidar com as situações de conflito ele vai caminhando para a operatividade. Além disso, o processo de aprendizagem, segundo Pichon-Rivière (2005), não ocorre de forma linear, mas dialética, ou seja, é marcado por momentos de tese, antítese e síntese. Quando o grupo supera um momento de conflito (tese e antítese), uma nova situação é gerada: a síntese anterior se torna agora ponto de partida para um novo "acontecer" grupal. Nesse momento o nível de ansiedade pode criar um bloqueio nos membros do grupo e gerar uma nova situação, promovendo, por exemplo, uma comunicação convergente, conforme nos mostra a figura 6.

É importante notar que, na configuração da figura 6, quem se destaca no grupo é outro aluno, mostrando, de alguma forma, que houve uma circulação dos papéis. Se essa configuração não evoluir, haverá necessidade de uma nova intervenção do professor para poder se perturbar novamente a rede de comunicação, saindo de um sistema convergente para uma rede difusa, evitando que esta se congele e volte à estereotipia. O grupo, então, experimenta um processo, que tem uma forma de espiral progressiva.

Pichon-Rivière (2005) descreveu esse processo como um cone invertido, cujo movimento segue a trajetória de uma espiral, partindo da ponta inferior para a parte superior, conforme a figura 7. Isso indica que o grupo segue do implícito para o explícito, cujos confli-
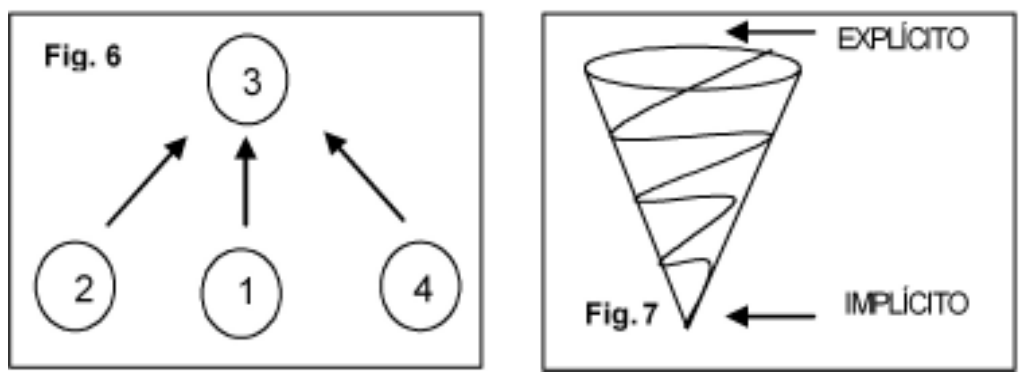

Fig. 6. O grupo experimenta uma nova situação de convergência, voltada agora para o aluno 3; Fig. 7. Cone invertido indicando o processo dialético com uma trajetória em espiral, do implícito para o explicito. 
Silva, G. S. F.; Villani, A.

tos são resolvidos no aqui e -agora grupal. Dessa forma, os sistemas de comunicação indicam os momentos do processo dialético, em que a principal característica é o fato de a quantidade de situações experimentadas transformarem-se em qualidade, por meio de saltos sucessivos (tese, antítese e síntese).

A figura da espiral corrobora a idéia de Bleger (2001) sobre a concepção operativa de aprendizagem, da qual nos apropriamos, afirmando que:

O termo aprender está bastante contaminado pelo intelectualismo; assim concebe-se o processo como a operação intelectual de acumular informação [...]; preferimos o conceito de que a aprendizagem é a modificação mais ou menos estável de linhas de conduta, entendendo-se por conduta todas as modificações do ser humano. [...]. A técnica operativa implica uma verdadeira concepção da totalidade do processo onde procuramos fazer com que toda informação seja incorporada ou assimilada como instrumento para voltar a aprender e continuar criando e resolvendo os problemas do campo científico [...]; no decorrer do ensino operativo, deve-se procurar caminhar para o desconhecido pois em ciência, não só se avança encontrando soluções, mas também, e fundamentalmente, criando problemas novos, e é necessário educar-se para perder o medo de provocá-los. (p. 67-9)

\section{As intervenções do professor no processo grupal}

Quando trabalhamos com grupos nas aulas (de Física), devemos buscar meios de evitar que seus membros se mantenham dispersos por muito tempo com a predominância da pré-tarefa. Ao fazermos isso, abrem-se duas possibilidades: se optamos por uma forma mais rígida de se manter o controle do grupo, corremos o risco de limitar a sua criatividade; mas, quando flexibilizamos demais algumas regras, há um risco de o grupo não conseguir sair dos níveis iniciais de funcionamento. Por essa razão, um aspecto importante no processo grupal e na técnica de grupos operativos é a figura do coordenador, que, no caso de um grupo de aprendizagem, passa a ser o professor.

Como cada grupo escreve sua própria história, o professor deve respeitar estas suas características peculiares sem pretender forçar a operatividade nem seu rendimento, possibilitando ao grupo trabalhar da melhor forma que ele pode e consegue. Nas suas intervenções, o professor deve buscar equacionar a situação descrita no parágrafo anterior: favorecer a operatividade do grupo sem limitar a sua criatividade.

Nas suas intervenções junto ao grupo, não podemos negligenciar o fato de que o professor se torna um membro do grupo, assumindo algum papel que lhe é transferido na relação com os alunos. Mas também não podemos negar o fato de que o professor exerce uma função normativa, que está associada à forma de tratar o tema em questão. Buscamos, neste momento, caracterizar as intervenções do professor, de acordo como se estabelece sua relação com os alunos. São elas: institucional e presencial. 
Grupos de aprendizagem nas aulas de Física: ...

\section{a) Intervenção Institucional}

Pensando na escola como uma instituição, professores, alunos, diretores, etc. exercem papéis diferentes, pois cada grupo possui uma tarefa específica. No que diz respeito ao professor, entre tantas outras, é sua função dar tarefas aos alunos, e quando ele o faz, no ambiente de aprendizagem, intervém no grupo de forma institucional.

Chamamos, então, de intervenção institucional aquela em que o professor age exercendo o seu papel perante uma instituição a que pertence, por exemplo: quando ele, em sala de aula, convoca os alunos para se reunirem em grupos, dando-lhes um exercício ou uma outra atividade para ser feita. Bleger (2001, p. 93) ainda afirma que "a forma de tratar o tema é o conteúdo normativo da tarefa". Relacionamos o aspecto normativo à intervenção institucional, que assume uma peculiaridade em nosso caso por causa da inserção e da rotatividade das funções (Líder, Anotador e Questionador) que foram outorgadas aos alunos para a realização da tarefa externa.

\section{b) Intervenção Presencial}

O aspecto normativo da tarefa pode limitar a criatividade do grupo, então para impedir este efeito, o professor precisa favorecer a comunicação e promover a circulação dos papéis. É por isso que, nos momentos em que o professor estiver de forma presencial, ele deverá "ajudar na constituição, no desenvolvimento e na manutenção do grupo - como equipe de trabalho - assumindo uma liderança democrática" (FERNANDES et al., 2003, p. 201), sem deixar que a comunicação sempre convirja para ele.

Quando o professor estiver presente entre os alunos, será necessário que esteja atento também para as mensagens que ele recebe dos alunos. Nesses momentos, o professor:

[...] deve procurar facilitar o diálogo e estabelecer a comunicação, incluindo-se aqui o respeito aos silêncios produtivos, criadores, ou que signifiquem um certo insight e elaboração [...]; deve ajudar o grupo a sair dos estereótipos, do já conhecido [...]; deve fazer o possível para estabelecer o diálogo entre os membros do grupo e não encampar tudo e nem centrar tudo em si. [...] Pode-se resumir as qualidades do coordenador em três palavras: arte, ciência e paciência. (BLEGER, 2001, p. 94-6)

\section{Análise dos dados}

Para a análise do desenvolvimento grupal, escolhemos um dos grupos da sala de aula, no qual percebemos mudanças ao longo do ano. A análise foi feita em duas etapas: na primeira foi privilegiado o aspecto diacrônico, podendo ser percebidas as mudanças mais significativas a passagem da pré-tarefa para uma nova organização tipo tarefa (GUIMARÃES, SILVA, VILLANI, 2005). Na segunda etapa procuramos aprofundar o entendimento dessa mudança, buscando identificar as várias configurações e sua sucessão, junto com os elementos que as influenciaram. 
Silva, G. S. F.; Villani, A.

\section{A análise diacrônica}

O grupo analisado era composto por quatro membros 5 : Valentim, Ricardo, Tito e Hernam. Este último se integrou aos membros restantes no segundo semestre, substituindo Kris, que se afastou da escola. O grupo foi observado enquanto resolvia os exercícios solicitados pelo professor na sala de aula.

Durante o primeiro semestre, a dinâmica grupal era fortemente controlada por um líder, Tito, que costumava tomar conta da tarefa totalmente. Ele anotava os resultados, se questionava e costumava agir também como porta-voz, manifestando ao professor as dúvidas e outras dificuldades do grupo. Além disso, congregava o grupo e exortava os membros a realizarem a tarefa. Podemos dizer que havia, nesse aluno, um sentimento de pertença. Havia, também, um reconhecimento dessa liderança por parte do grupo e dos demais alunos da turma, que sempre recorriam a ele em caso de dúvidas. Um outro aluno, Kris, tinha uma característica semelhante à de Tito, porém não chegava a ser reconhecido pelos demais membros do grupo. Ele também costumava opinar na tarefa e demonstrava ter algum conhecimento do conteúdo dos exercícios. Seria alguém que poderia competir pela liderança com Tito. Os outros dois alunos, Valentim e Ricardo, eram mais passivos dentro do grupo e demonstravam uma dependência da liderança. Ricardo era totalmente conformado com a situação, ao passo que Valentim costumava denunciar a liderança em certos momentos ou tentava exercê-la, sem muito sucesso.

As intervenções do professor durante o primeiro semestre foram ambíguas. Algumas vezes ele costumava reforçar a liderança de Tito, pois nos momentos em que era chamado a ir ao grupo (geralmente por Tito), ele mantinha um diálogo somente com ele. Parece claro que, nesses casos, as intervenções não foram eficientes para fazer emergir as ansiedades e os medos básicos, bem como perturbar a rede de comunicação do grupo, proporcionando a circulação de papéis e a quebra da estereotipia. Entretanto, em outros momentos, o professor ia até o grupo sem que fosse chamado, e suas intervenções (presenciais) conseguiam abrir o diálogo com todo o grupo, e não somente com Tito. Foi possível perceber que, nestas intervenções, Valentim e Ricardo pareciam participar mais. Geralmente, eles respondiam ao professor e gostavam de mostrar-lhe o que estavam fazendo nos exercícios. Esse fato possibilitou que os dois alunos começassem a se destacar mais durante as atividades.

Tendo em vista o funcionamento pouco satisfatório dos grupos de aprendizagem, no segundo semestre foi criado um mecanismo para estimular que todos os membros, em algum momento, tivessem uma participação mais ativa, quebrando a estereotipia que frequentemente se instaurava. Desse modo, os alunos receberam as funções de Líder, Anotador e Questionador $^{6}$ para desempenhar durante a atividade, segundo indicado em Heller et al. (1999).

\footnotetext{
${ }^{5}$ Os nomes são fictícios.

${ }^{6}$ Para evitar qualquer confusão com os papéis que Pichon indica, escrevemos as funções com as iniciais maiúsculas.
} 
O grupo analisado foi colocado numa nova situação que permitiu ou até estimulou uma participação mais ativa de todos os membros. A partir dessa intervenção (institucional) o grupo, agora composto por Tito, Hernam, Valentim e Ricardo, passou a ter uma postura diferente, o que significa que, enquanto os alunos faziam as tarefas, os papéis começaram a circular. Isso mostra certo salto qualitativo do grupo, pois uma vez que a liderança estava partilhada, eles não mais queriam voltar à situação anterior, criando, assim, uma nova rotina que, de certo modo, lhes era agradável.

Essa mudança, amparada pela autoridade do professor de fazer circular os papéis assumidos no grupo com a inserção das funções, parece ter ido ao encontro do anseio dos outros alunos, sobretudo os que apresentavam uma maior dependência em relação a Tito. Por exemplo, numa situação, ${ }^{7}$ observamos que Ricardo, após receber a função de Líder, abandonou sua dependência de Tito e tomou a iniciativa da resolução da tarefa, enquanto que este, assumindo outra função, ficou menos destacado no grupo. Isso ocorreu com mais frequência no final do ano. Por sua vez, Valentim, que costumava ser o porta-voz do grupo para denunciar a liderança de Tito, não se encontrava satisfeito ao exercer a função de Anotador, pois ele não só denunciava, mas também gostava de exercê-la. Em outra aula, Valentim estava na função de Líder, e perguntou várias vezes aos outros membros do grupo quem era o Líder, só para ouvir dos colegas a resposta de que ele era o Líder.

Essa análise, feita diacronicamente ao longo do ano letivo, nos apontou que o grupo apresentou uma mudança em sua configuração: após a inserção das funções, houve uma circulação dos papéis assumidos pelos alunos no processo de ensino-aprendizagem, o que possibilitou, ao grupo, um movimento geral seguindo da pré-tarefa para a tarefa. Ou seja, ainda que o grupo não tenha experimentado totalmente a fase da tarefa, conseguiu caminhar para a operatividade ao longo do ano.

A seguir, nossa análise sincrônica de duas aulas se foca justamente nessa transição: com base no detalhamento das interações será possível perceber a mudança dos sistemas de comunicação e os correspondentes efeitos no clima grupal. As aulas que serão analisadas se encontram no segundo semestre, portanto com a presença de Hernam e saída de Kris, sendo a primeira sem as funções e a outra já com a inserção delas.

\section{Primeira aula: o grupo na pré-tarefa}

Essa aula foi a primeira após as férias de meio de ano, e o professor ainda não havia outorgado as funções aos alunos. A atividade que o grupo tinha para fazer foi escrita na lousa, sendo constituída por questões adaptadas do livro texto usado na escola. Trata-se de um conjunto de exercícios tradicionais e semiabertos, cujo conteúdo envolvia os conceitos de Mecânica Newtoniana (identificação de forças, Leis de Newton e sua aplicação).

\footnotetext{
${ }^{7}$ Trata-se aqui de uma resolução de um exercício sobre cinemática de rotações e cuja distribuição das funções estava da seguinte forma: Ricardo, como Líder; Valentim era o Anotador, e os Questionadores eram Hernam e Tito. Percebemos o empenho do Ricardo chamando os seus colegas para a resolução de uma questão, e o descontentamento de Valentim com a sua função.
} 
Silva, G. S. F.; Villani, A.

O grupo permaneceu na pré-tarefa, indicando que não houve uma circulação dos papéis durante o fazer da atividade. Sua história pode ser sintetizada em algumas etapas principais, que indicamos na Figura 8; o nosso esforço, a partir de agora, se concentra na explicação das razões que levaram o grupo a permanecer nessa fase do processo grupal.

O início da formação do grupo se deu logo após o professor $(\mathrm{P})$ escrever a atividade na lousa e convocar toda a turma para se reunir em grupos. Identificamos, nesse momento, uma intervenção Institucional, no sentido do estabelecimento de uma norma para os alunos: "Prof. - Agora é com vocês! ... Então, sentem aí, comecem a fazer que daqui a pouco eu tô dando uma volta?"

Mesmo com essa intervenção perante o grupo-classe, ou seja, toda a turma, os alunos não formaram seus grupos tão prontamente. E, no caso do grupo que estamos analisando, Tito é quem reforça o pedido do professor e chama os seus colegas, assumindo o papel de líder progressista.

Configura-se inicialmente, no grupo, uma comunicação divergente, pois há um chamado de Tito para que se juntem e iniciem a atividade, mas esta configuração não permanece por muito tempo porque os demais lhe adjudicam o papel de líder democrático, passando a dominar no grupo uma comunicaşão convergente, indicada em 8 -a. Tito se torna depositário ${ }^{8}$ dessa liderança pelo fato de que ele apresenta um domínio do conteúdo, pois nos parece que é assim
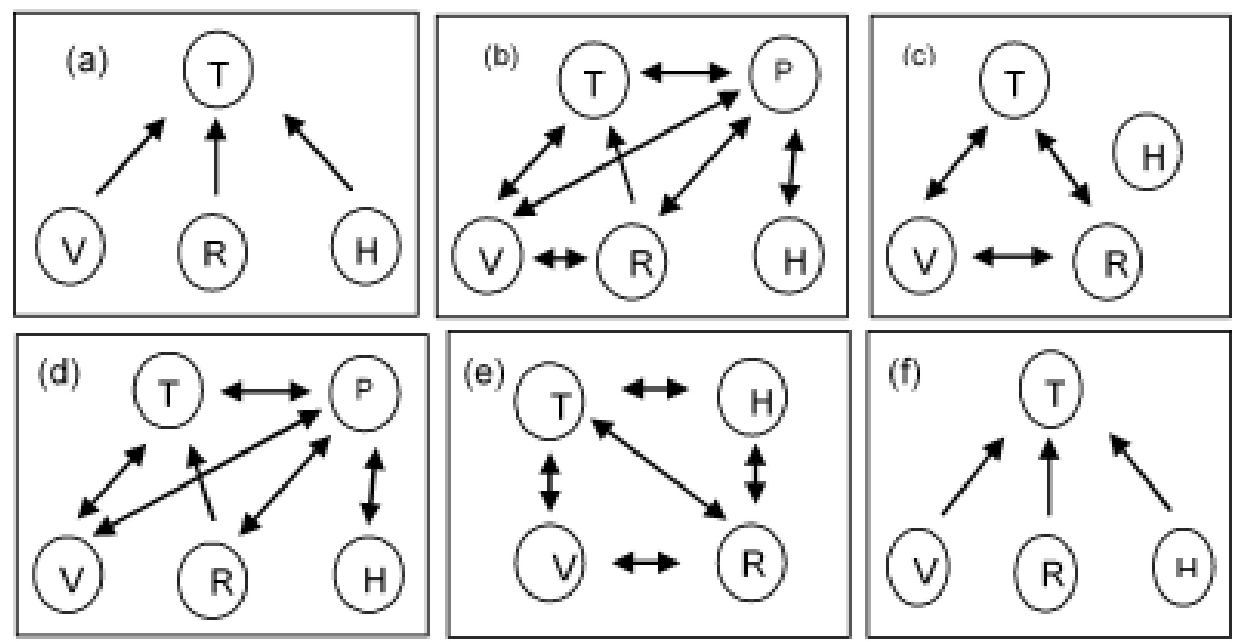

Fig. 8. Síntese do processo do grupo nesta aula, indicando a rede de comunicação entre os seus membros e as intervenções do professor.

\footnotetext{
${ }^{8}$ No que se refere a esse processo de assunção e atribuição de papéis, encontramos, na teoria do vínculo de Pichon-Rivière (2005), o que ele chama de "Teoria dos três D, que se refere ao depositário, depositante e depositado. O depositário é o objeto sobre o qual se situa o depósito, ou seja, em quem ou em que o sujeito faz a projeção de si ou de algo; o depositante é quem faz essa projeção; o depositado é o conteúdo transmitido nessa relação.
} 
Grupos de aprendizagem nas aulas de Física: ...

que os alunos "autorizam" o exercício da liderança no grupo. O trecho de uma fala, durante a resolução de um exercício no qual tinham de reconhecer o tipo de força, pode nos dar indício da convergência da comunicação para Tito.

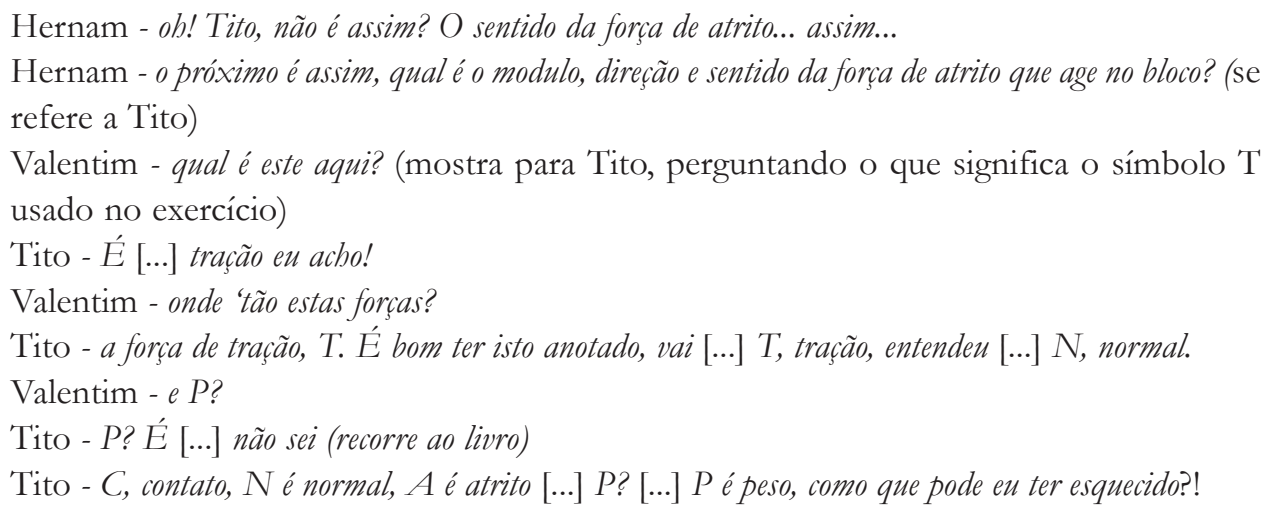

Vemos que Hernam e Valentim depositam a confiança na solução do exercício em Tito, que, por sua vez, aceita essa transferência feita pelos seus colegas de grupo e atua como um líder democrático. É interessante observarmos que "o papel adjudicado é o papel prescrito, ou o papel necessitado no grupo" (PICHON-RIVIÈRE, 2005, p. 145), ou seja, o papel de líder, que foi assumido por Tito, era o necessitado naquelas circumstâncias. Isso significa que "na medida em que os dois papéis coincidem - o prescrito e o assumido - produz-se o encaixe, a articulação" (PICHON-RIVIÈRE, 2005, p. 145), importante para a fluidez da comunicação (sistema difuso) bem como para a predominância dos vetores de cooperação e pertinência.

Numa outra ocasião, temos a configuração 8-b, em que o professor permanece presente no grupo e atua de forma presencial, no sentido de que ele tenta favorecer a comunicação entre os alunos (ele agora se torna um membro também). À medida que ele vai conversando com o grupo, os canais de comunicação vão se abrindo e configura-se uma comunicação difusa. Isso implica que aquela convergência da comunicação para Tito, a partir desse momento, vai sendo desfeita, de modo que o professor assume o papel de líder. Ele libera a comunicação dentro do grupo, ocorrendo o mesmo processo de encaixe entre o papel prescrito e o assumido: os alunos transferem os seus conteúdos implícitos para o professor, que aceita, abrindo-lhes os canais de comunicação.

O tema da conversa não está vinculado ao conteúdo específico da atividade, mas é sobre "o que é estudar e como fazế-lo". O professor vai conduzir a conversa para mostrar aos alunos que se pode estudar de várias maneiras.

Prof. - Sabe, o que acontece, às vezes a gente tem conceito diferente do outro do que é estudar. Então por exemplo, ele fala assim: ah estudei! O que é estudar para você??

Tito - Pra mim? Pra mim estudar é pegar no caderno resolver exercício, entender...

$[\ldots]$

Valentim - Professor, eu comecei agora!

Prof. - Agora que você começou a estudar! E em casa?

Valentim - Então!? 
Silva, G. S. F.; Villani, A.

Prof. - Então, o Valentim está estudando! .[...] Na medida em que vocês forem fazendo isto, vocês vão percebendo que... as coisas vão ficando mais fáceis e na medida em que fica mais fácil, é [...] parece que a gente tira um peso das costas [...].

Tito e o professor conversam por curto período até que Valentim também se interessa pelo assunto e interage com os dois e com os demais membros do grupo. Porém, ao deixar os alunos, o professor se mostra preocupado, pois o único que estava mais adiantado com os exercícios era Tito. E a sua preocupação ainda se concentrava em Hernam porque ele acabara de chegar à escola e estava um pouco defasado, em termos de conteúdo, em relação aos demais. Então, nesse contexto, ao sair do grupo, o professor se refere a Tito da seguinte forma: "Prof. - Dá uma mão para eles Tito, mas não a resposta. Isso que eu peço.. dá uma ajuda, mas assim, não seja muito Papai Noel. Qualquer coisa me chamem!"

Com essa fala, o professor atribui a Tito o papel de líder do grupo, e como tem um aspecto normativo, funciona como uma intervenção institucional. Nesse momento, o professor assume o papel de porta-voz do grupo, porque ele explicitou o que já vinha ocorrendo no grupo de forma latente, ou seja, os outros membros do grupo já depositavam em Tito esse papel, quando lhe pediam que os ajudasse com suas dúvidas. Tudo isso nos mostra que, para esses alunos, só poderia assumir o papel de líder quem tivesse o domínio do conteúdo.

Nas intervenções do professor há uma ambiguidade, que surge devido à forma de realizá-las, ou seja, quando ele atua de forma institucional, a norma implícita é que Tito sempre assuma o papel de líder e que os demais o vejam como tal. Porém, quando interage com o grupo de forma presencial, é ele quem assume esse papel, favorecendo a comunicação e desfazendo a convergência dos canais de comunicação para Tito, sem, no entanto, convergir tudo para si.

A figura 8-c representa uma situação na qual Hernam sofre uma exclusão no grupo: ainda que não seja uma configuração dominante entre eles, nesse momento mostra-se evidente. É atribuído a ele o papel de sabotador, pois além de ser um membro novo no grupo, ele se mostra, algumas vezes, capaz de competir pela liderança com Tito, no sentido de que ele se mostra conhecedor de parte do conteúdo. Por outro lado, Valentim e Ricardo o consideram uma ameaça porque Hernam também representa alguém a mais para depender de Tito. Mostramos, a seguir, algumas falas decorrentes desse episódio:

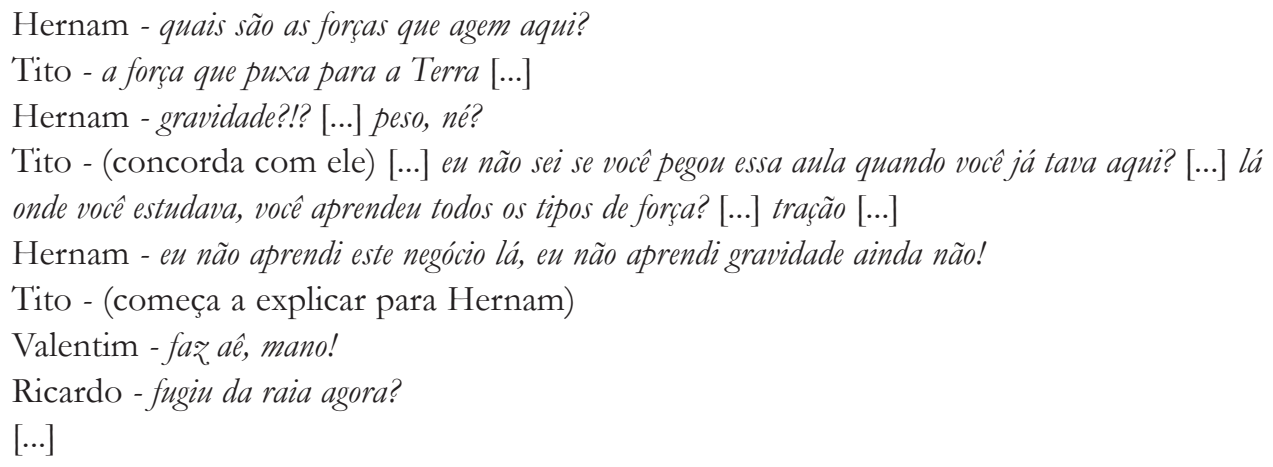


Grupos de aprendizagem nas aulas de Física: ...

Tito - o cara chegou agora na escola!

Ricardo - maior, cdf atrasado!!

Valentim - ô cdf atrasado!

A configuração da figura 8-c sofreu modificações com a presença do professor no grupo, que perturbou aquela rede de comunicações possibilitando que Hernam fosse aceito (figura 8-d). Ele assumiu, mais uma vez, o papel de líder ao possibilitar a comunicação entre os alunos, ajudando-os a superar os momentos de tensão. Podemos dizer então que uma consequência para os alunos foi a geração de um sistema comunicaşão difusa, mesmo que não tenha ocorrido de forma completa, pois os papéis ainda apresentavam alguma estereotipia (figura 8-e).

No entanto, o grupo, diante de uma nova situação, voltou a configuração de convergência para Tito, numa atribuição do papel de líder, ou seja, não houve uma mudança, um salto qualitativo, que os levaria a avançar para a fase da tarefa. Diante do novo, o grupo recorreu àquilo que já estava estabelecido: Tito deveria lhes "dar uma mão". O indício de mudança seria se o papel de líder, ao invés de pertencer a Tito, fosse atribuído a outro membro do grupo, como ocorrerá na aula seguinte.

Uma possível interpretação para esse fato pode ser encontrada em Pichon-Rivière (2005), quando ele fala sobre uma "inevitável presença, no campo da aprendizagem, do obstáculo epistemológico" (PICHON-RIVIÈRE, 2005, p. 11, grifo nosso). Para ele, ocorre uma fragmentação do objeto de conhecimento, formando domínios particulares (do conhecimento), como consequência da fragmentação do vínculo. Ora, a fragmentação ocorre dentro do grupo quando alguns de seus membros atribuem a Hernam o papel de sabotador e insistem na atribuição da liderança a Tito. O grupo experimenta aquilo que Pichon-Rivière (2005, p. 11) chama de momentos dipolares, "cumprindo assim dois processos de sinais contrários". Para superar isso, deveria ocorrer a "complementaridade através da experiência emocional corretora" (PICHON-RIVIÈRE, 2005, p. 11), que Pichon nomeia como epistemologia convergente.

Esse obstáculo gera um ruído na comunicação dos sujeitos e transforma a espiral dialética da aprendizagem em círculo fechado. O que está em jogo é o vínculo que "deve ser definido como mecanismo de interação que é ao mesmo tempo bicorporal e tripessoal" (PICHON-RIVIÈRE, 2005, p. 11, grifo nosso). Com isso o autor salienta simultaneamente a importância da presença física dos sujeitos que se mantém em comunicação e a perturbação desta comunicação por suas relações com um Outro ao qual prestam conta: "O perturbador de todo o contexto de conhecimento é o terceiro, cuja presença em nível do vínculo e do diálogo condiciona os mais graves distúrbios da comunicação e da aprendizagem" (PICHONRIVIÈRE, 2005, p. 11)

Em nosso caso, essa perturbação está associada à figura do professor, que, sem estar presente no grupo, interfere na forma de ruído na comunicação entre os alunos. Ou seja, aquele "comando inicial" permaneceu como um ruído impedindo os alunos de passarem por momentos de integração, que seria soltar da mão de Tito.

O que concluímos é que nessa aula, o grupo abre e fecha a atividade com uma comunicação convergente, o que não seria um problema, se não fosse o fato de que essa convergência é feita sempre para o mesmo aluno. Isso é típico de um grupo na pré-tarefa, indicando uma resistência à mudança e uma estereotipia do papel de líder, sempre assumido por Tito ou pelo professor. Entretanto, as intervenções que o professor fazia no grupo tinham, de um modo 
Silva, G. S. F.; Villani, A.

geral, algumas características que ora favoreciam a circulação dos papéis ora reforçavam a liderança de Tito. Nas figuras 8-b e 8-d, há uma representação do professor conseguindo minimizar o efeito da estereotipia e do aspecto normativo de suas intervenções institucionais, pois os gráficos seguintes, respectivamente, não nos mostram a convergência para T. Enquanto o professor estava presente no grupo, Ricardo mostrava-se interessado pela atividade desenvolvida, pois sempre apresentava, em seu caderno, o que ele estava fazendo. Esse é um fato significativo porque ele, até então, tinha tido uma participação pouco ativa.

Em resumo, o grupo não experimentou uma "epistemologia convergente" porque:

- Os alunos atribuíam a Tito e ao professor o papel de líder, considerando-os como aqueles detentores do conteúdo; isso impedia que as situações dilemáticas pudessem ser resolvidas a partir do diálogo entre todos;

- Havia ambiguidade nas intervenções do professor, que ora outorgava a Tito a liderança ora ele assumia esse papel;

- A intervenção institucional do professor no começo da aula representou, para os alunos, um caráter normativo, definindo a forma de tratar a tarefa (BLEGER, 2001): a sua realização deveria ser feita por meio da liderança de Tito. Essa intervenção funcionou como ruído na comunicação dos alunos.

\section{Segunda aula: o grupo na tarefa}

Essa aula ocorreu no fim do terceiro bimestre, quando as funções ${ }^{9}$ de Líder, Anotador e Questionadores já haviam sido outorgadas entre os alunos do grupo, e a escolha foi feita entre eles próprios: Hernam era o Líder, Tito era o Anotador, e Valentim e Ricardo eram os Questionadores. Como na aula anterior, a atividade consistia em um conjunto de exercícios retirados do livro texto e alguns elaborados pelo próprio professor, os quais estavam escritos na lousa. O conteúdo versava sobre energia e trabalho, e os alunos se concentraram nas discussões sobre as energias cinética, potencial gravitacional e potencial elástica. A atividade de grupo ocorreu no início da aula, pois os alunos teriam a prova bimestral logo em seguida, diferentemente da primeira aula em que o professor primeiro fez uma exposição do conteúdo e, depois, pediu que se formassem os grupos.

Entendemos que o grupo é marcado por uma saída da pré-tarefa em direção à tarefa. Nesta análise, procuramos identificar os seus principais momentos que nos apontem as razões dessa mudança, mapeando, assim, a sua história, que é indicada por meio dos gráficos mostrados na Figura 9.

\footnotetext{
${ }^{9}$ Estamos nos referindo às funções de Líder, Anotador e Questionador com suas letras iniciais maiúsculas para diferenciá-las dos papéis que os alunos assumem. Esses papéis são provenientes do referencial teórico de grupos operativos que estamos usando para conduzir a nossa análise.
} 

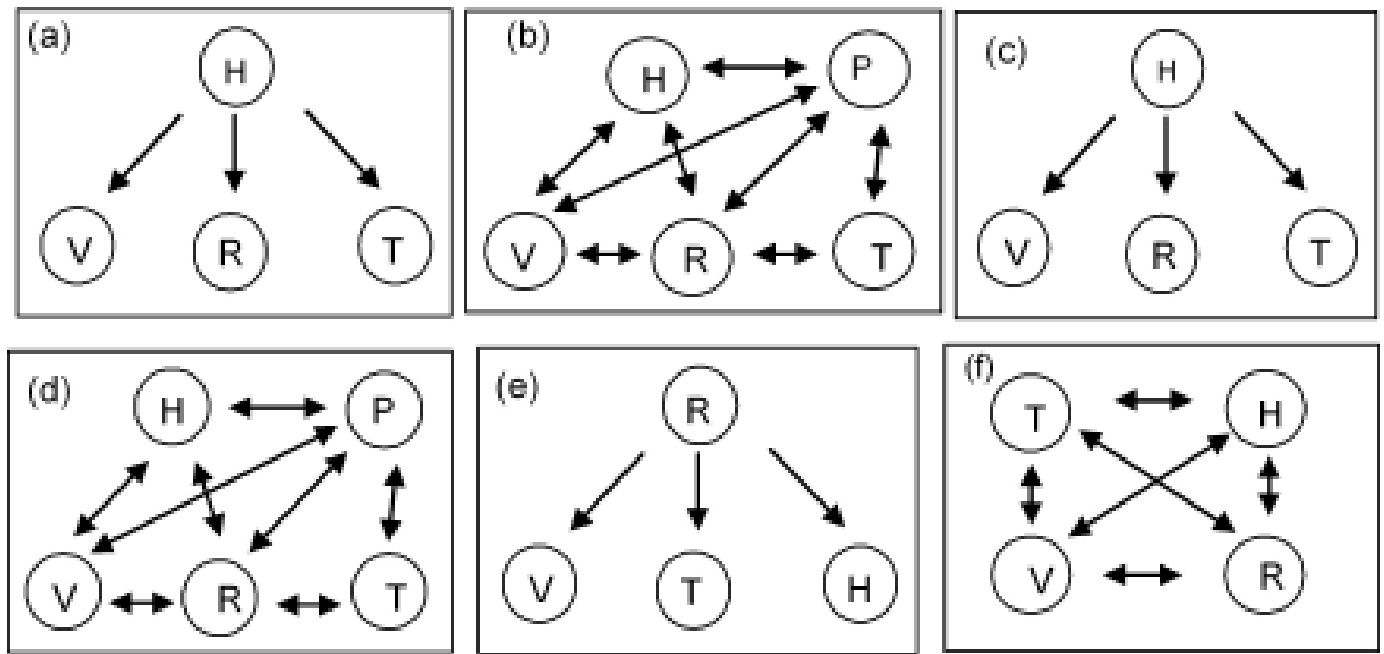

Fig. 9 - Momentos importantes da configuração do grupo; destaque para quando há uma mudança: R assume a liderança contribuindo para que a comunicação se torne difusa entre os alunos.

Tão logo o grupo se reúne, surge uma comunicação divergente (figura 9-a), partindo de Hernam para os demais. Ele, na função de Líder, assume o papel, ora de líder autocrático, querendo controlar o grupo, ora de laissez-faire, se eximindo de qualquer compromisso dentro do grupo. Podemos destacar algumas falas de Hernam, indicando o seu tipo de liderança:

Hernam - pergunta aí! Qual é a pergunta?

Tito - ta na lousa, lê!

Hernam - vamos ler o capitulo do livro primeiro!... todo mundo lendo o capitulo aí!

Tito - já li!

$[\ldots]$

Hernam - ob! O seguinte, eu ordeno que todo mundo leia o capitulo aí para entender!

Podemos identificar, nessa fala, que Tito se opõe à liderança de Hernam, pois neste momento inicial da atividade, o fato de ele estar em uma posição diferenciada em relação à outra aula - lá ele fora indicado líder pelo professor, aqui há outro ocupando esse papel - pode tê-lo incomodado. Isso, por si só, já nos parece indicar que as atribuições das funções neste grupo favorecem uma liderança partilhada. A análise diacrônica que fizemos mostrou que o grupo gostou desta nova situação, em que mais um pode estar na função de Líder (não necessariamente a exercerá como deveria) em aulas diferentes, uma vez que elas tinham de ser rotativas entre os alunos a cada atividade.

Na sequência, Ricardo tenta tomar alguma iniciativa para resolver a primeira questão, mas é interrompido por Tito. 
Silva, G. S. F.; Villani, A.

Ricardo - Quais as características [...]

Tito - Siga o líder! (interrompe Ricardo falando ironicamente)

Ricardo - Beleza! (ao falar isto, para de ler o exercício da lousa e pega o seu livro para ler o capitulo)

Podemos entender a fala de Tito de duas maneiras: o líder a que se refere é o Hernam, então se trata da função que este exerce, Líder; ou está se referindo a si próprio como líder. Essa diferenciação se faz mais clara na medida em que percebemos que o marcante da segunda aula é uma disputa pela liderança, no sentido de quem sabe mais o conteúdo. E a pergunta que pode ser feita é: que líder Ricardo deveria seguir?

Não há encaixe entre o papel adjudicado e o assumido por Hernam, tal como ocorria na primeira aula, o que causa a tensão gerada no grupo. A disputa pela liderança dura quase todo o tempo que o grupo está reunido, manifestando-se, algumas vezes, de forma mais intensa, como na seguinte fala:

Hernam - acho que é assim, ó (olha para Tito) energia cinética, energia cinética [...]

Ricardo - (fala ao Tito) a energia cinética você pode identificar ela quando [...] o corpo está em movimento.

Hernam - (responde ao Ricardo) é isto ai mesmo! O que ta escrito aqui é: a energia cinética é a energia $[\ldots]$

Tito - (inicia a leitura junto com Hernam, interrompendo-o)

Hernam - Dá licença! (fala para Tito). Dá licença! Dá licença! (enquanto ele fala isto, Tito continua lendo)

$[\cdots]$

Hernam - deixa eu explicar para vocês [...] a energia [...](continua o que estava lendo antes)

Se, por um lado, encontramos a disputa entre Tito e Hernam, por outro, percebemos que o grupo também experimenta momentos (dipolares) integradores, contribuindo para a superação daquele obstáculo (epistemológico) que, nessa aula, fora oferecido pela liderança autocrática de Hernam. Essa superação ocorre por dois motivos: 1) a disputa entre aqueles alunos abre um espaço para que os demais entrem na discussão, gerando uma comunicação difusa no grupo; 2) as intervenções presenciais do professor, que cumpre uma função dupla, atenuando os ruídos da comunicação gerada pelo comando inicial de Hernam e neutralizando uma ação polarizadora que a tarefa explícita oferece ao grupo. Ou seja, as atividades de Física tendem a favorecer aqueles alunos que têm o domínio do conteúdo, possibilitando a predominância das configurações de convergência ou divergência entre os alunos.

$\mathrm{Na}$ figura 9-b, vemos representada a atuação do professor abrindo os canais de comunicação com os alunos, bem como aceitando os pedidos que procedem deles. Nesse momento, o grupo atribui ao professor o papel de líder democrático, ocorrendo aquele encaixe entre o papel atribuído e assumido (PICHON-RIVIÈRE, 2005, p. 11), e uma suspensão da tensão entre os alunos devido àquela atuação de Hernam e Tito. Porém, logo após a saída do professor, observa-se, no grupo, uma nova divergência da comunicação, com um novo comando de Hernam (9-c), que segue assim até que surjam novos embates: "Hernam - vamos ler o capitulo do livro primeiro! [...] todo mundo lendo o capitulo aí?" 
Grupos de aprendizagem nas aulas de Física: ...

Passados alguns minutos dessa fala de Hernam, tanto ele quanto Tito começam um outro processo de argumentações para defender suas idéias, envolvendo os outros dois alunos, Valentim e Ricardo. O debate mais incisivo daqueles dois surge quando eles vão discutir a energia potencial gravitacional e quais grandezas físicas estariam a ela relacionadas. Na hipótese de Hernam, era a massa que influenciava: ele defendia que quando se têm dois ou mais objetos, o mais pesado chega primeiro ao solo quando todos são largados (com a mesma velocidade inicial) da mesma altura e ao mesmo tempo:

Hernam - tá associado (a energia potencial) à massa e à altura [...] porque dependendo do peso vai ter mais, [...] mais [...] inércia, quanto mais pesado, mais a gravidade vai [...]

Tito também lança a sua hipótese ao grupo dizendo:

Tito - a gente coloca que a energia potencial está associada à posição do corpo no campo gravitacional da Terra e a gente coloca que a energia potencial gravitacional está relacionada a altura também, ou não? (pergunta ao grupo)

Após as colocações de um e de outro, segue-se um pequeno debate, que é logo seguido por um momento de relaxamento do grupo. Podemos observar nessas falas como ambos atuam no grupo, e destacamos a forma democrática com a qual Tito explica o seu ponto de vista, pedindo a validação dos outros colegas.

As intervenções do professor no grupo são também sintetizadoras (figura 9-d), pois ele consegue interagir com os alunos de tal forma que todos participem. Ele retoma a energia cinética, dando mais uma explicação e, quando ele percebe que o grupo, com seu silêncio, indica que havia compreendido e completado um ciclo, ele então resgata a discussão sobre a energia potencial gravitacional. O dilema estava justamente nesse tópico e o professor consegue atuar no sentido de ajudá-los a encontrar um momento de síntese. A discussão não para aí, pois o professor amplia o debate introduzindo o tema da energia potencial elástica. Nesse momento o grupo experimenta, de fato, um salto por meio de um insight de Valentim sobre o assunto. Este aluno, responde ao professor sobre o significado de um símbolo na fórmula da energia potencial elástica.

Interpretamos como sendo um insight, porque a resposta de Valentim foi repentina, quando o professor já se preparava para sair do grupo, e nenhum dos outros alunos se manifestou neste sentido. Isso pode nos mostrar que os ciclos pelos quais o grupo passa estão associados àquele assentamento do conteúdo oferecido pelo professor, ou seja, os alunos, para resolverem os problemas da energia potencial gravitacional, não podiam estar com dúvidas sobre a energia cinética, e isto vale também para a energia potencial elástica. Não se trata aqui de uma exigência de pré-requisitos ou de uma sequência lógica, mas sim de uma exigência psicológica do sujeito que não consegue resolver um problema, se estiver preso a outro anterior. O professor, quando oferece aquelas sínteses, vem ao encontro dessa ansiedade do grupo, reduzindo-a e permitindo aquele insight de Valentim.

Após essa intervenção (9-d), há ainda a formação de um subgrupo, pois Tito e Hernam se juntam para resolverem sozinhos exercícios sobre os quais o professor havia fornecido explicação minutos antes. E, como consequência, surge um outro subgrupo entre Valentim e Ricardo, que estavam distraídos. Quando Ricardo percebe que os outros dois já haviam acabado, ele reclama que não estava entendendo nada, com o tom enfático da sua fala, acompanha- 
Silva, G. S. F.; Villani, A.

do por Valentim. Esse é um ponto marcante no grupo e pode indicar também outro momento de mudança, pois Ricardo assume o papel de porta-voz (figura 9-e) denunciando o subgrupo Hernam - Tito. A partir daí ele se torna líder (progressista), obtendo a concordância dos outros membros do grupo. Então, Hernam e Tito retomam a discussão a fim de explicar para Ricardo e Valentim o que eles fizeram; a partir dá gera-se, no grupo, uma comunicação difusa (9-f), quando se realiza, então, o encaixe dos papéis assumidos e prescritos no grupo.

Concluímos que, nesta aula, o grupo apresenta elementos que caracterizam um movimento em direção à tarefa, pois os papéis estão mais circulantes e a comunicação está mais fluida entre os alunos. No que diz respeito às intervenções do professor, podemos dizer que seus efeitos foram importantes para esse movimento do grupo, o aspecto normativo (inserção das funções) favoreceu a circulação dos papéis (sobretudo a liderança) entre os alunos, bem como a sua atuação presencial contribuiu para a atenuação dos ruídos na comunicação gerados pela atuação de Hernam. Apontamos ainda que, nesses momentos presenciais, o professor conseguia fazer com que os canais de comunicação abertos entre os alunos fossem mais duradouros. Enfim, aquela ambiguidade percebida na outra aula não estava tão presente.

\section{Considerações finais}

Analisamos o mesmo grupo em duas aulas diferentes e percebemos que, na primeira, havia uma dependência da liderança de Tito, que estava, em certo sentido, relacionada também com a liderança do professor, pois este atuava de forma ambígua em suas intervenções. Essa dependência teria impedido o grupo de vivenciar os momentos integradores. Hernam, que ainda não conhecia os mecanismos do grupo, sofreu uma exclusão porque ele se mostrou, em alguns momentos, capaz de contrastar o exercício da liderança ou, então, de se tornar alguém a mais para partilhá-la. Como mecanismo de defesa e de sobrevivência do grupo, foi-lhe atribuído o papel de sabotador.

Em contrapartida, na segunda aula, quando a liderança estava mais circulante no grupo, ela tornou-se objeto de disputa entre Tito e Hernam. Contudo, foi nesse processo de disputa que ocorreu a circulação dos papéis, pois, a partir do confronto de idéias entre os dois, o grupo conseguiu experimentar uma mudança. As intervenções do professor contribuíram bastante nesse sentido, ao possibilitarem ao grupo momentos de síntese e suspensão da tensão, muitas vezes, percebida entre os alunos devido àquela disputa. Sobre essa trajetória do grupo, Pichon-Rivière (2005, p. 12) afirma que:

o sujeito, à medida que apreende o objeto e o transforma, também modifica a si mesmo, entrando num jogo dialético, no qual a síntese que resolve uma situação dilemática se transforma em ponto inicial ou tese de outra antinomia, que deverá ser resolvida nesse continuo processo em espiral. 
É interessante perceber que o grupo, na segunda aula, cumpriu esse itinerário em que a rede de comunicação foi constantemente reajustada, sendo possível elaborar um pensamento capaz de um diálogo com o outro e de um confronto com a mudança (PICHON-RIVIÈRE, 2005).

No final, permanece a pergunta: Será que somente a inserção das funções como intervenção institucional foi suficiente para ajudar o grupo a experimentar mudanças, deslocandoo em direção à fase da tarefa? Apontamos que o que proporcionou ao grupo vivenciar uma mudança foi um conjunto de fatores: a atribuição de funções, as intervenções presenciais do professor, as características do próprio grupo e a tarefa.

Nas duas aulas houve uma intervenção do tipo institucional: na primeira foi aquele comando inicial que reforçava a liderança de Tito, enquanto, na segundam foi a inserção das funções, que provocou uma circulação maior do papel de líder entre os membros do grupo. Porém, aos dois tipos de intervenção normativa, foi acrescido um conjunto de intervenções do tipo presencial, no qual o professor se tornava membro do grupo, e conseguia favorecer a comunicação entre os alunos, produzindo aquele encaixe de papéis, mesmo que, na primeira aula, o grupo tenha permanecido na pré-tarefa.

A psicanálise pode nos ajudar a interpretar essa relação professor-aluno quando fazemos uso de um dos seus conceitos fundantes: a transferência. Trata-se do "processo pelo qual os desejos inconscientes se atualizam sobre determinados objetos no quadro de um certo tipo de relação estabelecida com eles [...].” (LAPLANCHE, PONTALIS, 1988, p. 668). Assim como o analisando atribui ao analista a função de saber sobre seus próprios desejos e necessidades, podemos pensar que, na sala de aula, também esteja em jogo um processo semelhante, cuja consequência seria o reconhecimento da autoridade do professor capaz de saber sobre os desejos e necessidades dos alunos. Isso explicaria por que os alunos aceitaram o professor como membro do grupo e por que essa autoridade atuava como ruído na comunicação dentro do grupo, no caso da primeira aula.

Podemos nos perguntar se a atribuição de funções teve o mesmo efeito em todos os grupos, já que a sala de aula investigada era composta por mais dois grupos. A resposta é não! Pois num outro grupo, por exemplo, havia uma liderança autocrática, que não foi abandonada nem mesmo com a inserção das funções. Assim, quando o aluno, que era reconhecido pelos colegas como líder, exercia a função de Anotador, era ele quem fazia sozinho todas as etapas das atividades e controlava as tarefas dos colegas. Isso nos dá indícios de que somente esse tipo de intervenção não garante uma mudança operativa no grupo (SILVA, VILLANI, 2008).

Um aspecto importante é a tarefa (explícita), porque se constitui um "organizador dos processos de pensamento, de comunicação e de ação que ocorrem na situação de grupo" (FERNANDES et al., 2003, p. 197). No caso do ensino da Física, a tarefa apresenta uma característica muito peculiar que está relacionada ao fato de que a resposta a ser alcançada é fixada a priori e, assim, haverá um resultado certo (ou errado). Esse fator favorece que, em um exercício de Física, haja uma polarização para aquele aluno que domina mais o conteúdo e, por conseguinte, apresenta alguma habilidade para resolvê-lo; como consequência, também é favorecida uma estereotipia dos papéis. Em suma, podemos dizer que, no caso de nosso grupo, na primeira aula, as intervenções do professor não equilibraram a tendência à polarização da 
Silva, G. S. F.; Villani, A.

tarefa, ao passo que, na segunda aula, tanto a estratégia institucional (inserção das funções) quanto as intervenções que o professor realizou presencialmente tenderam a formar uma situação de equilíbrio, no sentido contrário àquela polarização.

Como consideração final, podemos dizer que conhecer o processo de aprendizagem dos alunos nos grupos constitui uma informação importante para o professor poder regular as atividades de sala de aula e modificar suas intervenções. Isso implica dizer que, quando o professor opta por uma dinâmica que envolve grupos, o conhecimento do seu processo de desenvolvimento é muito importante para que as intervenções alcancem a meta visada. Pelo que pudemos notar em nossos casos, o ponto fundamental que deveria constituir objeto especial de análise do professor, que atua com pequenos grupos de aprendizagem, é a circulação ou não dos papéis, tanto dos alunos quanto de si próprio. Assim, por um lado, o professor deveria tentar explorar a relação de transferência que os alunos vivenciam em relação a ele, para favorecer a participação efetiva de todos e promover a circulação dos papéis nos grupos (como aconteceu na segunda aula). Isso se torna ainda mais importante quando existe uma forte liderança de algum membro do grupo. Por outro lado, às vezes, a relação de dependência dos alunos em relação ao professor, por ser demasiadamente intensa, não permite que surjam lideranças entre eles, pois entrariam em competição com a do docente (BAROLLI, 1998). Nesse caso, o professor deveria explorar os vínculos entre os alunos, reforçando-os para diminuir a dependência inicial.

Todas essas considerações nos remetem a um questionamento da opinião bastante compartilhada na área de Ensino de ciências, de que trabalhar com pequenos grupos é uma estratégia docente vitoriosa. Contudo, o resultado de nossa pesquisa e os de anteriores (BARROS, 2002) sugerem que a exploração de grupos de aprendizagem em sala de aula de ciências deve ser realizada quando o professor consegue ter um controle (relativo), cognitivo e afetivo, sobre os mesmos, ou seja, quando ele consegue entender o que ocorre nos vários grupos e, sobretudo, explorar a transferência pedagógica em favor do desenvolvimento dos mesmos. Sem essa noção mínima, os resultados podem ser mais insatifatórios do que a modalidade de instrução tradicional. 
Grupos de aprendizagem nas aulas de Física: ...

\section{Referências}

ANZIEU, D.; MARTIN, J. Y. La dinámica de los grupos pequeños. Buenos Aires: Kapelusz, 1971.

BAROLLI, E. Reflexões sobre o trabalho dos estudantes no laboratório didático. 191f. 1998. Tese (Doutorado em Educação) - Faculdade de Educação, Universidade de São Paulo, São Paulo, 1998.

BAROLLI, E.; VALADARES, J. M.; VILLANI, A. Explicitando uma metodologia de pesquisa: a experiência de uma professora de Física revisitada. Ciência \& Educação, Bauru, v. 13, n. 2, p. 253-71, 2007.

BARROS, J. A. et al. Engajamento interativo no curso de Física da UFJF. Rev. Brasileira de Ensino Física, São Paulo, v. 26, n. 1, p. 63-9, 2004.

BARROS, M. A. Análise de experiências didáticas com grupos de aprendizagem em física. 212f. 2002. Tese (Doutorado em Educação) - Faculdade de Educação, Universidade de São Paulo, São Paulo, 2002.

BLEGER, J. Grupos operativos no ensino, In: Temas de Psicologia: entrevistas e grupos. 2. ed. São Paulo: Martins Fontes, 2001. p. 59-111.

BRASIL. Parâmetros Curriculares Nacionais: Ensino Médio. Secretaria de Educação e Tecnológica. Brasília: MEC, SENTEC, 2002.

COLL, C. Os conteúdos na reforma. Porto Alegre: Arte Médicas, 2000.

FERNANDES, L. M. Um olhar winicottiano sobre a relação dos estudantes com o próprio processo de aprendizagem. 112f. 2007. Dissertação (Mestrado em Ensino de Ciências - modalidade Física) - Instituto de Física, Faculdade de Educação, Universidade de São Paulo, São Paulo, 2007.

FERNANDES, W. J. et al. Grupos e configurações vinculares. Porto Alegre: Artes Médicas, 2003

GUIMARÃES, L. F.; SILVA, G. S. F.; VILLANI, A. Grupos de aprendizagem: o papel da intervenção do professor. In: ENCONTRO NACIONAL DE PESQUISA EM EDUCAÇÃO EM CIÊNCIAS, 5., 2005, Bauru. Anais... Bauru, 2005. 1-CD-ROM.

HAKE, R. Interactive-engagement vs. traditional methods: a six thousand student survey of mechanics test data for introductory physics courses. American Journal of Physics, Melville, NY, v. 66, n. 1, p. 64-74, 1998.

HELLER, P. et al. Cooperative group problem solving in Physics. Mentor TA guide, 1999: guide for the instructors of the orientation. University of Minnesota, 1999.

Disponível em: <http://groups.physics.umn.edu/physed/>. Acesso em: 27 out. 2008.

KIRSCHNER, P. A. Epistemology, practical work and academic skills in science education. Science \& Education, Springer Netherlands, v. 1, n. 3, p. 273-99, 1992. 
Silva, G. S. F.; Villani, A.

LAPLANCHE, J.; PONTALIS, J-B. Vocabulário de Psicanálise. 10. ed. São Paulo: Martins Fontes, 1988.

LÜDKE, M.; ANDRÉ, M. E. D. A. Pesquisa em educação: abordagens qualitativas. Temas básicos da educação e ensino. São Paulo: EPU, 1986.

MOREIRA, M. A. Pesquisa em ensino: o Vê epistemológico de Gowin. São Paulo: EPU, 1990.

PICHON-RIVIÈRE, E. O processo grupal. 7. ed. São Paulo: Martins Fontes, 2005.

ROCHA, Z. F. D. C. Análise da dinâmica de um grupo de aprendizagem em Ciências no Ensino Fundamental. 140f. 2005. Dissertação (Mestrado em Ensino de Ciências e Educação Matemática) - Universidade Estadual de Londrina, Londrina, 2005.

SANTOS, F. M. T.; GRECA I. M. (Orgs.). A pesquisa em ensino de ciências no Brasil e suas metodologias. Ijuí: Unijuí, 2006.

SILVA, G. S. F. As intervenções do professor e o processo grupal nas aulas de Física: uma análise à luz da teoria de grupos operativos. 240f. 2008. Dissertação (Mestrado em Ensino de Ciências-modalidade Física) - Instituto de Física/Faculdade de Educação, Universidade de São Paulo, São Paulo, 2008.

SILVA, G. S. F.; VILLANI, A. O processo grupal nas aulas de Física: a análise do grupo da resistência. In: ENCONTRO DE PESQUISADORES EM ENSINO DE FÍSICA, 10., 2008, Curitiba. Anais... Curitiba: SBF, 2008. 1 CD-ROM.

VILLANI, A. et al. Contribuições da Psicanálise para uma Metodologia de Pesquisa em Educação em Ciências. In: SANTOS, F. M. T.; GRECA, I. M. (Orgs.). A pesquisa em ensino de Ciências no Brasil e suas metodologias. Ijuí: Ed. Unijuí, 2006. p. 323-90.

Artigo recebido em maio de 2008 e aceito em dezembro de 2008 